\title{
ANALISIS MONITORING PELAKSANAAN PEKERJAAN PROYEK PASAR RAKYAT BARENG KOTA MALANG
}

\author{
Faris Rizal Andardi ${ }^{* 1}$, Wisnumurti ${ }^{2}$, Agus Suharyanto ${ }^{3}$ \\ ${ }^{1}$ Mahasiswa / Magister / Teknik Sipil / Univeritas Brawijaya \\ ${ }^{2}$ Dosen / Teknik Sipil / Universitas Brawijaya Malang \\ ${ }^{3}$ Dosen / Teknik Sipil / Universitas Brawijaya Malang \\ Korespondensi : farisrizal159@gmail.com
}

\begin{abstract}
Curve-S, Earned Value, and Tracking. The results of the analysis using the curve method S, week 1 to 6 project acceleration took place, while at week 17, 18, and 19 projects too late. At week 20 the work is accelerated until the last week of the 22nd week, and the duration of the last project is 22 weeks. The result of analysis using Earned Value method, week 17,18,19 late, and other week happened acceleration. Cost deviations occur in weeks 1-4,6,7,15,16,17, and 18. To estimate the final cost of the total final cost, and the prediction for the total project completion time is 22 weeks. The analysis result using tracking shows that the actual duration is 158 days, and the estimated duration is 2 calendar days. The project prediction is completed on January 28, 2017. The total cost incurred is less than the final project cost plan. So the recommendation of the appropriate monitoring method for the People's Market is Tracking.
\end{abstract}

Keywords : Curve-S, Earned Value, Tracking, Recommended Monitoring Method

\section{PENDAHULUAN}

Pasar Rakyat Bareng terletak di tengah kota, di Jl. Terusan Ijen berhadapan dengan Masjid Quba. Proyek pasar Rakyat Bareng adalah proyek revitalisasi dengan cara merobohkan bangunan lama menjadi konstruksi baru.

Pekerjaan sebuah proyek perlu dilakukan monitoring untuk melihat kemajuan yang telah dicapai dan biaya yang dikeluarkan. Tiga metode yang telah diciptakan dalam memonitoring sebuah proyek adalah Kurva S, Earned Value, dan Tracking. Ketiga metode diatas digunakan untuk analisis monitoring pelaksanaan pekerjaan proyek pasar Rakyat Bareng kota Malang. Hal ini dikarenakan ketiga metode masing-masing mempunyai kelebihan dan kekurangan. Untuk itu bila digambarkan dalam pekerjaan konstruksi rekomendasi mana yang lebih baik dalam analisis monitoring sebuah proyek konstruksi, terutama untuk proyek pasar Rakyat Bareng kota Malang.
Berdasarkan penelitian terdahulu Fariyadin (2016) [1], metode earned value menunjukkan keterlambatan dari pekerjaaan proyek dan menunjukkan kerugian biaya selama pekerjaan proyek berlangsung. Sedangkan menurut penelitian Hatumale (2016) [2[, Tracking bisa menekan kembali periode waktu proyek sehingga kembali seperti yang direncanakan dan mampu mengurangi biaya akibat keterlambatan proyek.

Tujuan dalam penelitian ini adalah sebagai berikut:

1. Menganalisis pelaksanaan pekerjaan pasar Rakyat Bareng dengan metode Kurva-S

2. Menganalisis pelaksanaan pekerjaan pasar Rakyat Bareng dengan metode Nilai Hasil (Earned Value)

3. Menganalisis pelaksanaan pekerjaan pasar Rakyat Bareng dengan metode Tracking, dan pengaruhnya terhadap total durasi.

4. Mendapatkan rekomendasi metode yang terbaik dalam monitoring pelaksanaan pekerjaan pasar Rakyat Bareng 


\section{TINJAUAN PUSTAKA}

\subsection{Kurva-S (S-Curve)}

Kurva $S$ adalah grafik yang dikembangkan oleh Warren T. Hanumm atas dasar pengamatan terhadap sejumlah proyek besar sejak awal hingga akhir proyek. Kurva $S$ dapat menunjukkan kemajuan proyek berdasarkan kegiatan, waktu, dan bobot pekerjaan yang dipresentasikan sebagai persentase kumulatif dari seluruh proyek [3]

\subsection{Earned value}

Menurut Abrar Husen (2011) [3], dalam penentuan kinerja proyek dengan cara Earned Value, informasi yang ditampilkan berupa indikator-indikator dalam bentuk kuantitatif, yang menampilkan informasi progress biaya dan jadwal proyek. Indikator ini menginformasikan posisi kemajuan proyek dalam jangka waktu tertentu serta dapat memperkirakan proyeksi kemajuan proyek pada periode selanjutnya.

Indikator-indikator tersebut adalah sebagai berikut :

1. BCWS (Budgeted Cost of Work Shedule), menggambarkan anggaran rencana sampai pada periode tertentu terhadap volume rencana proyek yang akan dikerjakan.

2. BCWP (Budigeted Cost of Work Performed), menggambarkan anggaran rencana proyek pada periode tertentu terhadap apa yang telah dikerjakan pada volume pekerjaan aktual.

3. ACWP (Actual Cost of Work Performed), menggambarkan anggaran aktual yang dihabiskan untuk pelaksanaan pekerjaan pada keadaan volume pekerjaan aktual.

\subsection{Pelacakan (Tracking)}

Tracking adalah proses pelacakan jadual yaitu membandingkan antara jadual rencana dengan progress aktual dari pekerjaan yang telah dilaksanakan setiap periode waktu. Perhitungan perbedaan antara jadual rencana dengan progress aktual pada tracking berdasarkan bobot durasi pekerjaan, sementara pada kurva $\mathrm{S}$ berdasarkan bobot biaya pekerjaan [4].

\section{METODOLOGI PENELITIAN}

Data-data proyek yang mendukung analisis penelitian ini adalah

a. Rencana anggaran biaya (RAB) proyek pasar Rakyar Bareng Kota Malang b. Biaya akuntan proyek

c. Master Schedule proyek pasar Rakyat Bareng Kota Malang

d. Laporan Progress mingguan

e. Dokumentasi kegiatan proyek pembangunan pasar Rakyat Bareng

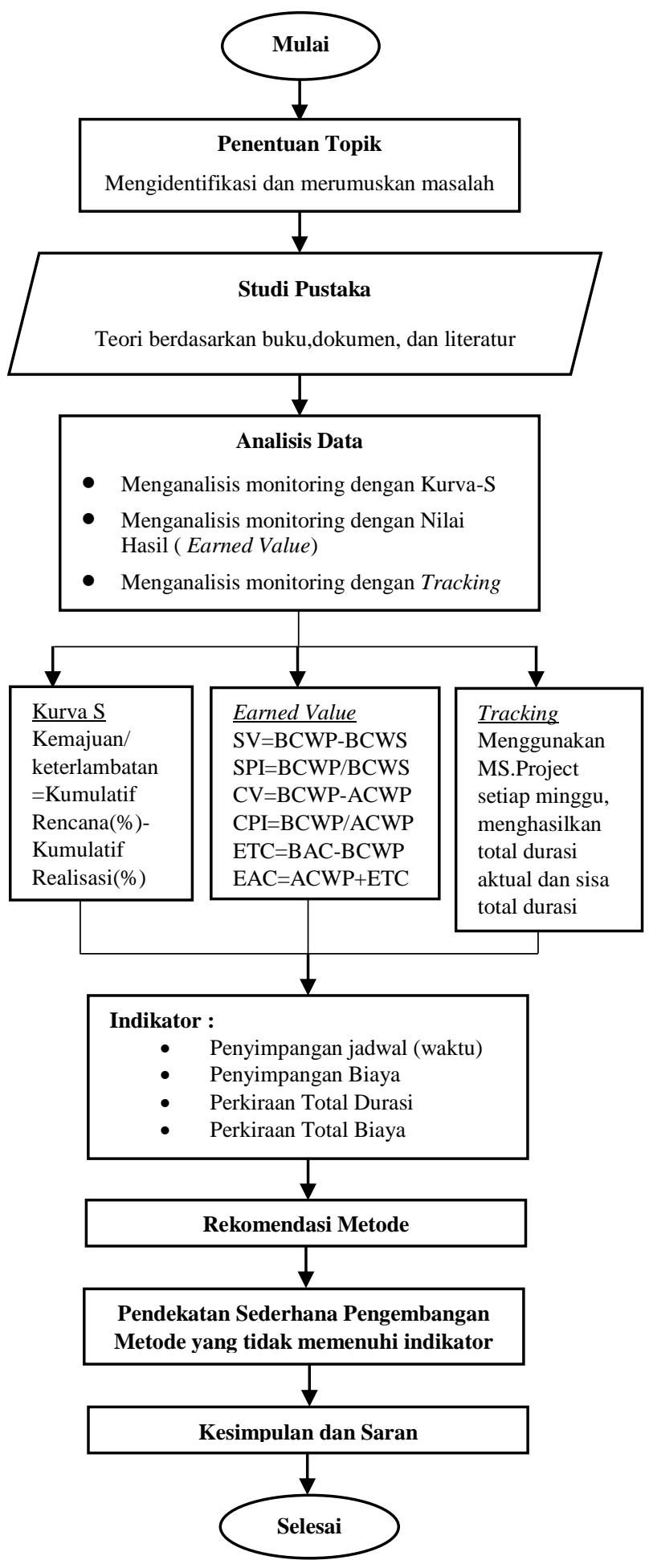

Gambar 1. Bagan diagram alir penelitian 


\section{HASIL DAN PEMBAHASAN}

\subsection{Analisa kurva-S proyek Pasar Rakyat Bareng}

Tabel 1. Hasil analisa minggu ke-1 sampai minggu ke-4

\begin{tabular}{|l|c|c|c|c|}
\hline \multirow{2}{*}{} & \multicolumn{4}{|c|}{ Minggu Ke- } \\
\cline { 2 - 5 } & $\mathbf{1}$ & $\mathbf{2}$ & $\mathbf{3}$ & $\mathbf{4}$ \\
\hline Rencana(\%) & 1,41 & 3,35 & 6,21 & 6,22 \\
\hline Kumulatif Rencana(\%) & 1,41 & 4,77 & 10,98 & 17,19 \\
\hline Realisasi(\%) & 1,69 & 3,78 & 6,22 & 7,12 \\
\hline Kumulatif Realisasi(\%) & 1,69 & 5,48 & 11,69 & 18,81 \\
\hline Prestasi Pekerjan (\%) & 0,28 & 0,71 & 0,72 & 1,61 \\
\hline
\end{tabular}

Tabel 2. Hasil analisa minggu ke-5 sampai minggu ke-8

\begin{tabular}{|l|c|c|c|c|}
\hline \multirow{2}{*}{} & \multicolumn{4}{|c|}{ Minggu Ke- } \\
\cline { 2 - 5 } & $\mathbf{5}$ & $\mathbf{6}$ & $\mathbf{7}$ & $\mathbf{8}$ \\
\hline Rencana(\%) & 2,53 & 1,36 & 5,72 & 5,43 \\
\hline Kumlatif Rencana(\%) & 19,73 & 21,08 & 26,81 & 32,24 \\
\hline Realisasi(\%) & 2,24 & 9,54 & 9,05 & 4,49 \\
\hline Kumulatif Realisasi(\%) & 21,05 & 30,59 & 39,64 & 44,13 \\
\hline Prestasi Pekerjan (\%) & 1,32 & 9,50 & 12,83 & 11,89 \\
\hline
\end{tabular}

Tabel 3. Hasil analisa minggu ke- 9 sampai minggu ke-12

\begin{tabular}{|l|c|c|c|c|}
\hline \multirow{2}{*}{} & \multicolumn{4}{|c|}{ Minggu Ke- } \\
\cline { 2 - 5 } & $\mathbf{9}$ & $\mathbf{1 0}$ & $\mathbf{1 1}$ & $\mathbf{1 2}$ \\
\hline Rencana(\%) & 5,02 & 4,36 & 4,39 & 4,04 \\
\hline Kumlatif Rencana(\%) & 37,26 & 41,62 & 46,01 & 50,05 \\
\hline Realisasi(\%) & 3,73 & 2,37 & 2,48 & 10,24 \\
\hline Kumulatif Realisasi(\%) & 47,86 & 50,23 & 52,71 & 62,95 \\
\hline Prestasi Pekerjan (\%) & 10,60 & 8,61 & 6,70 & 12,90 \\
\hline
\end{tabular}

Tabel 4. Hasil analisa minggu ke-13 sampai minggu ke-16

\begin{tabular}{|l|c|c|c|c|}
\hline \multirow{2}{*}{} & \multicolumn{4}{|c|}{ Minggu Ke- } \\
\cline { 2 - 5 } & $\mathbf{1 3}$ & $\mathbf{1 4}$ & $\mathbf{1 5}$ & $\mathbf{1 6}$ \\
\hline Rencana(\%) & $\mathbf{7 , 0 1}$ & $\mathbf{7 , 8 8}$ & 6,14 & 3,40 \\
\hline Kumlatif Rencana(\%) & 57,06 & 64,94 & 71,08 & 74,47 \\
\hline Realisasi(\%) & 2,17 & 3,58 & 8,48 & 1,13 \\
\hline Kumulatif Realisasi(\%) & 65,12 & 68,70 & 77,18 & 78,31 \\
\hline Prestasi Pekerjan (\%) & 8,06 & 3,76 & 6,11 & 3,84 \\
\hline
\end{tabular}

Tabel 5. Hasil analisa minggu ke-17 sampai minggu ke-20

\begin{tabular}{|l|c|c|c|c|}
\hline \multirow{2}{*}{} & \multicolumn{4}{|c|}{ Minggu Ke- } \\
\cline { 2 - 5 } & $\mathbf{1 7}$ & $\mathbf{1 8}$ & $\mathbf{1 9}$ & $\mathbf{2 0}$ \\
\hline Rencana(\%) & 4,94 & 5,14 & 5,99 & 4,70 \\
\hline Kumlatif Rencana(\%) & 79,41 & 84,55 & 90,54 & 95,24 \\
\hline Realisasi(\%) & 0,51 & 0,08 & 10,94 & 6,20 \\
\hline Kumulatif Realisasi(\%) & 78,82 & 78,91 & 89,85 & 96,05 \\
\hline Prestasi Pekerjan (\%) & $-0,59$ & $-5,65$ & $-0,69$ & 0,81 \\
\hline
\end{tabular}

Tabel 6. Hasil analisa minggu ke-20 sampai minggu ke-22

\begin{tabular}{|l|c|c|}
\hline \multirow{2}{*}{} & \multicolumn{2}{|c|}{ Minggu Ke- } \\
\cline { 2 - 3 } & $\mathbf{2 1}$ & $\mathbf{2 2}$ \\
\hline Rencana(\%) & 3,49 & 1,22 \\
\hline Kumlatif Rencana(\%) & 98,73 & 100,00 \\
\hline Realisasi(\%) & 3,48 & 0,47 \\
\hline Kumulatif Realisasi(\%) & 99,53 & 100,00 \\
\hline Prestasi Pekerjan (\%) & 0,80 & 0,00 \\
\hline
\end{tabular}

\subsection{Analisa earned value proyek Pasar Rakyat Bareng}

Tabel 7. Hasil analisa penyimpangan jadwal (SV) dan penyimpangan biaya $(\mathrm{CV})$

\begin{tabular}{|c|c|c|c|c|}
\hline Bulan & $\begin{array}{c}\text { Minggu } \\
\text { Ke- }\end{array}$ & Periode & $\begin{array}{c}\text { CV } \\
(\mathbf{R P}) \\
\end{array}$ & $\begin{array}{c}\text { SV } \\
\text { (Rp) }\end{array}$ \\
\hline Juli & 1 & $27-31$ & -6.965 .117 & 21.975 .592 \\
\hline \multirow[t]{5}{*}{ Agustus } & 2 & $1-7$ & -22.537 .834 & 55.723 .824 \\
\hline & 3 & $8-14$ & -48.125 .994 & 56.194 .729 \\
\hline & 4 & $15-21$ & -77.427 .237 & 126.752 .078 \\
\hline & 5 & $22-28$ & 9.275 .769 & 103.756 .190 \\
\hline & 6 & $29-4$ & -106.055 .511 & 745.992 .880 \\
\hline \multirow[t]{4}{*}{ September } & 7 & $5-11$ & -215.462 .447 & 1.006 .953 .041 \\
\hline & 8 & $12-18$ & 107.875 .540 & 933.177 .838 \\
\hline & 9 & $19-25$ & 154.868 .059 & 831.933 .144 \\
\hline & 10 & $26-2$ & 184.756 .359 & 676.220 .374 \\
\hline \multirow[t]{5}{*}{ Oktober } & 11 & $3-9$ & 215.929 .365 & 525.609 .082 \\
\hline & 12 & $10-16$ & 344.878 .550 & 1.012.289.971 \\
\hline & 13 & $17-23$ & 383.012 .932 & 632.661 .611 \\
\hline & 14 & $24-30$ & 200.494 .795 & 295.257 .782 \\
\hline & 15 & $31-6$ & -231.508 .931 & 475.379 .156 \\
\hline \multirow[t]{4}{*}{ November } & 16 & $7-13$ & -289.004 .181 & 297.533 .825 \\
\hline & 17 & $14-20$ & -315.027 .275 & -50.072 .957 \\
\hline & 18 & $21-27$ & -319.305 .044 & -446.889 .370 \\
\hline & 19 & $28-4$ & 24.272 .049 & -57.999 .867 \\
\hline \multirow[t]{3}{*}{ Desember } & 20 & $5-11$ & 120.104 .570 & 59.491 .068 \\
\hline & 21 & $12-18$ & 177.384 .517 & 59.098 .647 \\
\hline & 22 & $19-23$ & 185.116 .158 & 0 \\
\hline
\end{tabular}

Pada minggu ke-1-4, 6, 7, 15, dan 16 pekerjaan terlaksana lebih cepat dengan biaya lebih kecil dari pada anggaran. Minggu ke-5, 814, 20 dan 21 pekerjaan terlaksana lebih cepat dari jadual dengan biaya lebih kecil dari anggaran. Pada mingggu ke-17 dan 18 pekerjaan selesai terlambat dan menelan biaya lebih tinggi dari pada anggaran. Minggu ke-19 pekerjaan selesai terlambat dan menelan biaya 
lebih rendah dari pada anggaran. Sedangkan, pada minggu terakhir atau minggu ke-22 pekerjaan terlaksana tepat waktu dengan biaya lebih kecil dari anggaran.

Selanjutnya, dilakukan perhitungan EAC ditinjau dalam dua kondisi, yaitu pada saat prestasi mingguan pekerjaan mencapai prosentase di bawah $50 \%$ dan di atas $50 \%$, dengan besar total biaya rencana (Basic of Budgeted Cost at Completion atau BAC) yang ditentukan sebesar Rp7.848.425.885,07,

Untuk perhitungan Penyelesian proyek, diasumsikan bahwa kecenderungan angka kinerja waktu yang terjadi pada saat pelaporan akan tetap sampai akhir proyek.

$$
\mathrm{TE}=A T E+\frac{(O D-(A T E x S P I))}{S P I}
$$

Tabel 8. Hasil analisa perkiraan biaya akhir proyek (EAC) dan perkiraan waktu penyelesaian proyek (TE)

\begin{tabular}{|c|c|c|c|c|}
\hline Bulan & $\begin{array}{c}\text { Minggu } \\
\text { Ke- }\end{array}$ & Periode & $\begin{array}{l}\text { EAC } \\
(\mathbf{R p})\end{array}$ & $\begin{array}{c}\text { TE } \\
\text { (Hari) }\end{array}$ \\
\hline Juli & 1 & $27-31$ & 7.855.391.002 & 73 \\
\hline \multirow[t]{5}{*}{ Agustus } & 2 & $1-7$ & 7.870 .963 .719 & 77 \\
\hline & 3 & $8-14$ & 7.896 .551 .879 & 83 \\
\hline & 4 & $15-21$ & 7.925 .853 .122 & 80 \\
\hline & 5 & $22-28$ & 7.839 .150 .116 & 82 \\
\hline & 6 & $29-4$ & 7.954 .481 .396 & 61 \\
\hline \multirow[t]{4}{*}{ September } & 7 & $5-11$ & 8.063 .888 .332 & 60 \\
\hline & 8 & $12-18$ & 7.740 .550 .345 & 64 \\
\hline & 9 & $19-25$ & 7.693 .557 .826 & 69 \\
\hline & 10 & $26-2$ & 7.480 .634 .431 & 73 \\
\hline \multirow[t]{5}{*}{ Oktober } & 11 & $3-9$ & 7.438 .762 .707 & 77 \\
\hline & 12 & $10-16$ & 7.300 .538 .695 & 70 \\
\hline & 13 & $17-23$ & 7.260 .242 .999 & 77 \\
\hline & 14 & $24-30$ & 7.556 .593 .340 & 83 \\
\hline & 15 & $31-6$ & 8.148 .366 .199 & 81 \\
\hline \multirow[t]{4}{*}{ November } & 16 & $7-13$ & 8.217 .458 .474 & 84 \\
\hline & 17 & $14-20$ & 8.248 .079 .897 & 89 \\
\hline & 18 & $21-27$ & 8.253 .075 .600 & 94 \\
\hline & 19 & $28-4$ & 7.821 .412 .219 & 89 \\
\hline \multirow[t]{3}{*}{ Desember } & 20 & $5-11$ & 7.723 .379 .481 & 87 \\
\hline & 21 & $12-18$ & 7.670 .203 .724 & 87 \\
\hline & 22 & $19-23$ & 7.663 .309 .727 & 88 \\
\hline
\end{tabular}

\subsection{Analisa tracking proyek Pasar Rakyat} Bareng

Berdasarkan hasil perhitungan tracking didapatkan bahwa percepatan pekerjaan proyek pasar Rakyat Bareng terjadi pada Minggu ke1,2,3,dan 4. Keterlambatan terjadi pada minggu ke-5 sampai 22. Biaya lebih besar dari rencana terjadi pada minggu ke-1,2, dan 3 . Biaya lebih kecil dari rencana terjadi pada minggu ke-4 sampai minggu ke-22. Perkiraan total durasi 26 minggu berbeda dengan yang direncanakan Perkiraan Total Biaya sebesar Rp 7.529.756.208; sedangkan anggaran rencana sebesar Rp 7.848.425.885,07.

Tabel 9. Hasil analisa tracking minggu Ke-1 sampai minggu ke-22

\begin{tabular}{|c|c|c|c|}
\hline $\begin{array}{c}\text { Minggu } \\
\text { Ke- }\end{array}$ & $\begin{array}{c}\text { \%kumulatif } \\
\text { Hasil } \\
\text { pelaporan }\end{array}$ & $\begin{array}{c}\text { \% Complete } \\
\text { Hasil } \\
\text { Tracking }\end{array}$ & $\begin{array}{l}\text { Biaya } \\
\text { Aktual } \\
\text { (Rp) }\end{array}$ \\
\hline 1 & 1,69 & 4 & 133.052 .289 \\
\hline 2 & 5,47 & 6 & 429.873 .316 \\
\hline 3 & 11,69 & 13 & 918.457 .689 \\
\hline 4 & 18,81 & 16 & 1.254 .083 .770 \\
\hline 5 & 21,05 & 24 & 1.429 .010 .481 \\
\hline 6 & 30,59 & 31 & 2.176 .759 .840 \\
\hline 7 & 39,64 & 37 & 2.886 .786 .445 \\
\hline 8 & 44,13 & 39 & 3.239 .482 .887 \\
\hline 9 & 47,86 & 43 & 3.532 .399 .314 \\
\hline 10 & 50,24 & 45 & 3.718 .611 .458 \\
\hline 11 & 52,71 & 47 & 3.912 .876 .103 \\
\hline 12 & 62,95 & 58 & 4.714.984.558 \\
\hline 13 & 65,12 & 60 & 4.885 .393 .863 \\
\hline 14 & 68,7 & 63 & 5.166 .650 .644 \\
\hline 15 & 77,18 & 76 & 5.832 .234 .890 \\
\hline 16 & 78,31 & 78 & 5.895 .170 .534 \\
\hline 17 & 78,82 & 78 & 5.935 .295 .696 \\
\hline 18 & 78,91 & 79 & 5.941 .715 .721 \\
\hline 19 & 89,85 & 84 & 6.756 .913 .809 \\
\hline 20 & 96,04 & 88 & 7.257.139.77 \\
\hline 21 & 99,53 & 96 & 7.529 .756 .208 \\
\hline 22 & 99,99 & 99 & 7.607.196.945 \\
\hline
\end{tabular}


Tabel 10. Hasil analisa tracking minggu Ke-1

\begin{tabular}{cllll}
\multicolumn{5}{c}{ Sampai minggu ke-22 (lanjutan) } \\
\hline Minggu & Biaya & Prediksi & Aktual & $\begin{array}{l}\text { Remain- } \\
\text { ing }\end{array}$ \\
Ke- & Pelaporan & Penyelesaian & $\begin{array}{l}\text { Duration } \\
\text { Duration }\end{array}$ \\
& (Rp) & & (Hari) & (Hari) \\
\hline 1 & 132.804 .490 & 24-Jan-17 & 5,54 & 149,62 \\
2 & 429.715 .142 & 24-Jan-17 & 9,42 & 145,74 \\
3 & 917.606 .813 & 24-Jan-17 & 19,84 & 135,32 \\
4 & 1.476 .217 .660 & 24-Jan-17 & 25,38 & 129,78 \\
5 & 1.652 .167 .126 & 24-Jan-17 & 36,74 & 118,42 \\
6 & 2.400 .958 .397 & 24-Jan-17 & 48,05 & 107,11 \\
7 & 3.111 .132 .760 & 24-Jan-17 & 57,28 & 97,88 \\
8 & 3.463 .865 .252 & 24-Jan-17 & 60,76 & 94,4 \\
9 & 3.756 .788 .630 & 24-Jan-17 & 67,45 & 87,72 \\
10 & 3.943 .044 .572 & 24-Jan-17 & 70,02 & 85,14 \\
11 & 4.137 .306 .459 & 27-Jan-17 & 75,38 & 83,42 \\
12 & 4.940 .648 .037 & 27-Jan-17 & 92,77 & 66,03 \\
13 & 5.111 .127 .560 & 27-Jan-17 & 95,88 & 62,92 \\
14 & 5.392 .512 .959 & 28-Jan-17 & 100,2 & 59,08 \\
15 & 6.058 .183 .690 & 28-Jan-17 & 121,43 & 37,85 \\
16 & 6.146 .798 .506 & 28-Jan-17 & 124,14 & 35,14 \\
17 & 6.186 .906 .717 & 28-Jan-17 & 124,99 & 34,29 \\
18 & 6.193 .499 .848 & 28-Jan-17 & 125,13 & 34,15 \\
19 & 7.052 .302 .214 & 28-Jan-17 & 133,56 & 25,72 \\
20 & 7.538 .498 .509 & 28-Jan-17 & 140,24 & 19,04 \\
21 & 7.811 .877 .964 & 28-Jan-17 & 152,5 & 6,78 \\
22 & 7.848 .425 .885 & 28-Jan-17 & 157,25 & 2,03 \\
\hline & & & & \\
& & & & \\
\hline
\end{tabular}

\subsection{Rekapitulasi hasil analisa metode kurva S, earned value, dan tracking}

Tabel 11. Hasil rekapitulasi

\begin{tabular}{|l|c|c|c|}
\hline Review & Kurva-S & $\begin{array}{c}\text { Earned } \\
\text { Value }\end{array}$ & Tracking \\
\hline Indikator & $\bullet$ Minggu ke-1 & $\bullet$ Minggu ke & Percepatan \\
Penyimp & sampai & $17,18,19$ & terjadi pada \\
angan & minggu ke- & terjadi & Minggu ke- \\
Jadual & 16 proyek & keterlamba & $1,2,3,4$, \\
(waktu) & mengalami & -tan & Keterlambata \\
& percepatan & Sisa & n terjadi pada \\
& Minggu ke- & Minggu & Minggu ke-5 \\
& 17,18, dan 19 & lainnya & sampai 22 \\
& proyek & mengalami & \\
& mengalami & percepatan & \\
& keterlambata & & \\
\hline
\end{tabular}

\begin{tabular}{|l|c|c|c|}
\hline Review & Kurva-S & $\begin{array}{c}\text { Earned } \\
\text { Value }\end{array}$ & Tracking \\
\hline main- & $\mathrm{n}$ & & \\
\hline Minggu ke- & &
\end{tabular}


Pada metode kurva $\mathrm{S}$, indikator yang telah dibuat peneliti yang dapat terjawab adalah indikator penyimpangan jadwal, sedangkan indikator penyimpangan biaya, indikator total durasi dan indikator perkiraan total biaya tidak mampu terjawab di kurva $\mathrm{S}$.

Pada metode Earned Value ketiga indikator yang dibuat oleh peneliti seperti penyimpangan jadwal, penyimpangan biaya, perkiraan total biaya mampu terjawab, sedangkan indikator yang tidak dapat dianalisa sepenuhnya adalah perkiraan total durasi yang tidak memperhitungkan keterlambatan akibat original duration yang ditetapkan tetap di angka 88 hari,. Sedangkan, pada metode tracking semua indikator mampu terjawab.

\subsection{Pendekatan sederhana pengembangan metode}

Setelah dilakukan analisa setiap periode dan dikaitkan dengan ketiga metode yaitu kurva S, earned value, dan tracking yang tidak memenuhi dari kriteria indikator yang telah dibuat dari awal adalah Kurva-S dan Earned Value. Dari keempat indikator hanya tracking yang mampu mejawab, sehingga diperlukan pendekatan sederhana pengembangan untuk metode kurva-S dan Earned Value . Pendekatan sederhana untuk dapat menjawab semua indikator peneliti melakukan dengan cara trial and error.

\subsubsection{Pendekatan sederhana pengembangan} kurva-S

Kurva $\mathrm{S}$ dapat memonitoring proyek pasar Bareng dengan menghasilkan prestasi pekerjaan, yang menjawab salah indikator penyimpangan jadwal (waktu). Kendala memonitoring jadwal seperti ini kadang kala juga mengalami kekurangan, karena pada pekerjaan yang terlambat tetapi bukan masuk pada lintasan kritis belum bisa dikatakan terlambat. Sehingga perlu dilakukan pengecekan Free Sleck dan Total Slack, dan dikatakan pekerjaan tersebut tidak mengalami keterlambatan.

Solusinya adalah penambahan total slack pada kurva S. Berikut adalah kurva-S pada minggu ke-1 sampai minggu ke-4.

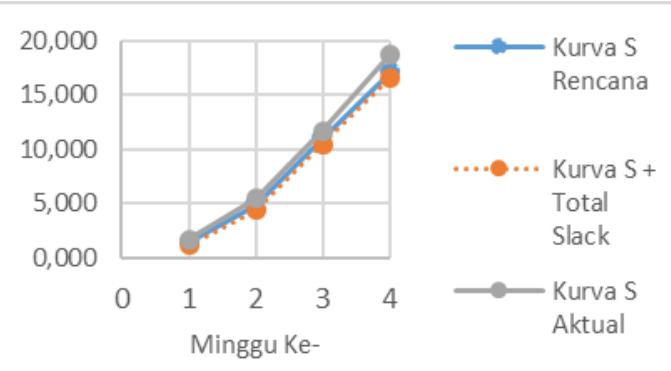

Gambar 2. Kurva-S setelah penambahan total slack

Untuk pendekatan penyimpangan biaya maka digunakan rumus sebagai berikut :

Minggu ke- =

[ $\frac{\text { 96 Kumwiatif Ahtual }}{100 \% 6} \times$ Total Biaya]

[ $\frac{96 \text { Kumulatif Rencana }}{10076} \times$ Total Biaya]

Pada minggu pertama pada proyek pasar Rakyat Bareng setelah dihitung dengan rumus diatas didapatkan biaya aktual sebesar Rp 132.796.693,94, sedangkan rencana anggaran biaya sebesar Rp 132.804.489,64. Sehingga ada penyimpangan anggaran yang sebesar Rp7.795,70(-).

Untuk pendekatan indikator perkiraan total durasi, peneliti kembali menggunakan rumus dasar perhitungan prestasi kerja dan durasi pekerjaan. Dimana :

Prestasi kerja $=\frac{\text { UpahHarian }}{\text { Analisa } \text { Vpah }}$

Durasi Pekerjaan $=\frac{\text { Volume Peherjaan }}{\text { Prestagi Kerja }}$

Sehingga, Perkiraan Penambahan durasi

pekerjaan $=\frac{\text { sisa progress kemajuan } x \text { wol.total }}{\text { Prestasi } \mathrm{Kerja}}$

Contoh pada proyek pasar Bareng yang mengalami keterlambatan pada minggu ke-17. Direncanakan dua minggu yaitu minggu ke 13, dan 18, sedangkan pada pelaksanaanya dilakukan pada minggu ke $15,16,17,18$, dan 19.

Diketahui:

- Volume $=1333,630 \mathrm{~m}^{2}$

- Prestasi kerja rencana yang telah dikonversi ke dalam minggu $=666,82$ $\mathrm{m}^{2} /$ minggu

- Durasi rencana $=2$ minggu 
Perkiraan Penambahan durasi pekerjaan $=$

$$
\frac{1,023 x 1,333,630}{666,82}=2 \text { minggu }
$$

Sehingga pelaporan pada minggu ke 17 , perkiraan total durasi adalah 5 minggu. Jumlah 5 minggu ini sesuai dengan progres kemajuan kurva $S$ aktual dimana membutuhkan 5 minggu.

Untuk pendekatan indikator perkiraan total biaya, peneliti mencoba rumus prediksi total Biaya ahir adalah

$=($ Biaya yang dikeluarkan pada minggu ke- $)+($ Total anggaran Proyek Pasar Bareng - Rencana Anggaran

pada minggu ke-)

Diketahui :

Biaya yang dikeluarkan pada minggu ke-2 $=\mathrm{Rp} \quad 429.715 .141,79$

Total Angaran Proyek Pasar Bareng $=$ Rp7.848.425.885,07

Rencana anggaran pada miggu ke-2

$$
=\operatorname{Rp} \quad 429.705 .614,26
$$

Sehingga, Prediksi biaya total yang harus dikeluarkan adalah :

$$
\begin{aligned}
& =429.715 .141,79+(7.848 .425 .885,07 \text {. } \\
& \text { 429.705.614,26) } \\
& =7.848 .435 .412,59
\end{aligned}
$$

\subsubsection{Pendekatan sederhana pengembangan earned value}

Pada dasarnya metode Earned Value sudah menjawab semua indikator yang dibuat peneliti sebelumnya yaitu penyimpangan jadwal (waktu), penyimpangan biaya, perkiraan total durasi, dan perkiraan total biaya. Kelemahan yang dapat terlihat pada metode earned value ini terletak pada perkiraan total waktu penyelesai proyek yang masih menggunakan asumsi bahwa kecenderungan angka kinerja waktu yang terjadi pada saat pelaporan akan tetap sampai akhir proyek. Kenyataan berdasarkan kemajuan di lapangan dilaporkan terjadi keterlambatan. Sehingga peneliti mencoba rumus :

Durasi Tambahan ( DT) $=\frac{\text { sisa volume }}{\text { prestasi herja }}$

$\mathrm{TE}=\frac{\text { sisa waktu }+D T}{\mathrm{sPI}}+$ waktu terpakai
Contoh pada saat pelaporan proyek pasar Bareng pada minggu ke-17 yang mengalami keterlambatan

$$
\begin{aligned}
& \text { DT }=\frac{1333,630 \mathrm{~m}^{2}-662,82 \mathrm{~m}^{2}}{267 \mathrm{~m}^{2} / \text { minggu }}=3 \text { minggu } \\
& \mathrm{TE}=\frac{5+3}{0,99}+17=25 \text { minggu }
\end{aligned}
$$

\section{KESIMPULAN DAN SARAN}

\subsection{Kesimpulan}

1. Setelah dilakukan analisa terhadap pasar Bareng di kota Malang dengan metode kurva S didapatkan bahwa pada minggu ke1 sampai minggu ke-16 proyek mengalami percepatan. Pada minggu ke-17,18, dan 19 proyek mengalami keterlambatan. Pada minggu ke-20 pekerjaan proyek mengalami percepatan sampai pada minggu terakhir yaitu minggu ke 22. Durasi yang direncanakan pada akhir proyek di kurva $\mathrm{S}$ rencana sama dengan durasi aktual yaitu selesai pada minggu ke 22 .

2. Hasil analisa menggunakan metode Earned Value, penyimpangan jadwal yang berbeda dengan rencana terjadi pada minggu ke 17,18,19 atau terjadi keterlambatan, dan sisa minggu lainnya mengalami percepatan. Penyimpangan biaya yang terjadi pada minggu ke-1 sampai minggu ke 17 atau dapat dikatakan berbeda dengan biaya yang direncanakan. Untuk prediksi total biaya akhir sebesar Rp 7.663.309.727; dan prediksi untuk waktu total penyelesaian proyek pasar Bareng adalah 22 minggu sesuai dengan yang direncanakan.

3. Hasil Analisa menggunakan metode tracking pada awal sampai akhir proyek terlihat bahwa percepatan terjadi pada Minggu ke-1,2,3,4. Keterlambatan terjadi pada Minggu ke-5 sampai 22. Biaya lebih besar dari rencana terjadi pada minggu ke$1,2,3$. Biaya lebih kecil dari rencana terjadi pada minggu ke-4 sampai minggu ke-22. Perkiraan total durasi 26 minggu berbeda dengan yang direncanakan. Perkiraan total biaya sebesar Rp 7.529.756.208; sedangkan anggaran rencana sebesar $\mathrm{Rp}$ 7.848.425.885.07

4. Berdasarkan pada analisa perhitungan menggunakan ketiga metode yaitu kurva $S$, Earned Value, dan Tracking, kurva S dan Earned Value mempunyai kekurangan jika dibandingkan dengan metode tracking 
sehingga rekomendasi metode monitoring yang sesuai untuk pasar Bareng adalah Tracking.

\subsection{Saran}

1. Pendekatan pengembangan sederhana metode sebaiknya diaplikasikan juga untuk beberapa proyek besar, sehingga akhirnya pengembangan sederhana pada kedua metode yang dihasilkan dapat diterapkan atau tidak pada semua proyek di Indonesia dan digunakan oleh semua kalangan.

2. Pada saat melakukan monitoring menggunakan ketiga metode tersebut, sebaiknya peneliti selanjutnya turut andil bekerja di proyek yang akan diteliti, sehingga memudahkan dalam mendapatkan dan mengolah data hasil lapangan.

\section{DAFTAR PUSTAKA}

[1]Fariyadin, Adiman. (2016). Evaluasi Pengendalian Pelaksanaan dan Penjadwalan Proyek Perpipaan di Kota Malang. Tesis. Tidak dipublikasikan. Malang : Universitas Brawijaya Malang.

[2]Hatumale, Yohanes Sefanus Jong. (2016). Analisis Percepatan waktu Penyelesaian Proyek Menggunakan metode Fast Track dan Crash Program ( Studi kasus : Proyek Hotel Dewarna Tahap II Bojonegoro). Tesis. Tidak dipublikasikan Malang : Universitas Brawijaya Malang.

[3]Husen, Abrar. (2011). Manajemen Proyek. Yogyakarta: Andi Yogyakarta.

[4]Saifoe,Controlling-Kurva S-Tracking http://www.saifoemk.lecture.ub.ac.id, diakses 1September 2016. 